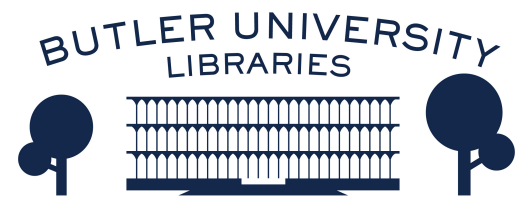

Journal of Hindu-Christian Studies

Volume 31 Celebrating Rāmānuja at 1000: The

Heritage and Promise of the Study of Rāmānuja

in a Christian-Hindu Comparative Theology

Article 28

2018

\title{
VIEWPOINT: Rethinking My Religion
}

Bradley Malkovsky

University of Notre Dame

Follow this and additional works at: https://digitalcommons.butler.edu/jhcs

\section{Recommended Citation}

Malkovsky, Bradley (2018) "VIEWPOINT: Rethinking My Religion," Journal of Hindu-Christian Studies: Vol. 31, Article 28.

Available at: https://doi.org/10.7825/2164-6279.1705

The Journal of Hindu-Christian Studies is a publication of the Society for Hindu-Christian Studies. The digital version is made available by Digital Commons @ Butler University. For questions about the Journal or the Society, please contact cbauman@butler.edu. For more information about Digital Commons @ Butler University, please contact digitalscholarship@butler.edu. 


\title{
VIEWPOINT: Rethinking My Religion
}

\author{
Bradley Malkovsky \\ University of Notre Dame
}

WHEN Gopal Gupta, my successor as editor of this journal, kindly invited me to write this year's Viewpoint piece, I agreed, but with great hesitation, not knowing if I would have anything new or meaningful to contribute to thinking about contemporary Hindu-Christian engagement. In the intervening months since Gopal's invitation, I have considered many possible themes, but I have finally rejected all of them, as one by one they ended up seeming not so very important or timely, after all. But I eventually came to recognize that there was something far more important slowly emerging in my mind that I might articulate and bring to print, and that I should do this as honestly as possible.

What I have slowly come to realize was just how much my thinking about Christianity and Christian doctrine has changed over the past four decades and how much this change was due to my long encounter with other religions, especially with Hinduism. I first discussed this with the late Noel Sheth, SJ (1943-2017) a few years ago. Noel, a Catholic priest and professor, was a great Sanskritist from India who had contributed much to Hindu-Christian scholarship as well as to cordial relations between Hindus and Christians. His advice came as a warning: what you say out loud is one thing, but putting it into print is another. If you put something into print that doesn't easily conform to Catholic teaching, the Catholic authorities will have an easier time coming after you. But I will offer this brief reflection, anyway, not knowing its outcome and hoping for the best.

Perhaps instead of calling these changes in myself a kind of theological development, they might be better termed a process of undevelopment in theological matters, a kind of unlearning, a gradual whittling away of some things I once held dear and essential to what it means to be a Christian, and in their place has emerged a gradual relearning of what is truly important. This is a development I never could have imagined earlier in my life, especially during my many years in Germany when I was studying Christian theology with some very famous Catholic and Protestant theologians, prior to going to India.

During my time in Germany in the late 1970s and early 1980s I was continually reminded of the central importance of Christian doctrine. Both in Catholic and Protestant faculties of theology German scholars have long been unrivalled in their ability to trace the development and importance of Christian teaching through the ages, starting with its foundation in the New Testament, continuing through the patristic and medieval eras, and finally arriving at modernity and our own contemporary world. Always one of the big themes was fidelity, i.e. faithfulness in changing times to what God

Bradley Malkovsky teaches comparative theology at the University of Notre Dame in the U.S. and was previously the editor of the Journal of Hindu-Christian Studies. 
had definitively given to humanity for all times through the unsurpassable revelation in Christ.

There was an assumption during those days of the obvious superiority of Christian teaching over all the other teachings of the world religions. Not that the subject of other religions came up very often in the classroom. When religions were mentioned at all, it was always in sweeping statements, the implication being that other religions were on uncertain and doubtful ground with regard to truth and salvation. We didn't even have to bother to really look at them or see what they were about; the superiority of our doctrines was something that could be safely assumed, because we had Christ, and the other religions didn't. Part of this lack of interest in other religions also had to do with more urgent spiritual and cultural issues that needed addressing at the time, for example, the rise of secularism, materialism, and atheism in the West. But perhaps the bigger problem was ignorance. It is a sobering fact that there were no Christian theologians anywhere in Germany at the time I was studying theology who knew enough about Hinduism, Buddhism or Islam to speak about them with any authority in the classroom or in writing. ${ }^{1}$

The contrast with today cannot be greater. Nowadays the issue of the salvation of members of other religions has faded for many (not all) Christians, as they have come to know Hindus, Muslims, and Buddhists first-hand in an ever-shrinking world and have seen for themselves the goodness and even holiness manifested in the lives and faces of these people. The holiness of others is recognizable across religious and doctrinal divides. And from the Christian perspective holiness is always a fruit of the Holy Spirit. St. Paul, in his New Testament Letter to the Galatians 5:22-23, lists the transformative effects of the Holy
Spirit in the following way: "The fruit of the Spirit is love, joy, peace, patience, kindness, generosity, faithfulness, gentleness, and selfcontrol." One sees these fruits of the Spirit both in Christians and in people of other religions.

Now if people of other religions are made holy by God it seems to me they should not be excluded from salvation just because they espouse doctrines that contradict Christian teaching. I am thinking here of the Muslim rejection of the Trinity and of the divinity of Christ, the Buddhist rejection of a creator God, and the Hindu teaching of reincarnation and its rejection of the Christian teaching of one earthly life. The Catholic Church's Vatican II document from 1965, Nostra Aetate, formally recognized the presence of truth and holiness in other religions. The unsaid implication here is that people of other religions can be saved, ${ }^{2}$ even if they embrace teachings that contradict Christian teaching.

All of this affirmation of the value of other religions as places where holiness is communicated does not mean that Christian teaching is now unimportant. I believe the central teachings of Christianity are relevant for all humanity, namely that God is love, that God was revealed in a decisive way for the good of all people in the life of Christ, that the resurrection is real, that all human beings have infinite dignity and value, that to be spiritual is not only to orient oneself to a deepened interior spiritual life, but also to work for peace and justice in the world, to work for the Kingdom of God, which was at the center of Jesus' teaching. The standard Christian teaching, moreover, is that Christ definitively reveals God's will to the world as well as the final aim of human life, which is loving communion between all people and between people and God. 
In fact, I think that it is better for all people - even holy people of other religions - to be familiar with the story of Jesus as given in the New Testament than it is to be ignorant of that life. And many people of other religions have indeed come to know the story of Jesus in at least a partial sense, and they find that story attractive and inspiring: There is probably no human being in history who has been so variously interpreted and adopted by other religions as has Jesus. His life in service to others, his renunciation of family life for the sake of God, his radical teaching of divine love, his fellowship with the poor and marginalized of society, and his example of patient suffering have endeared him to many. But at the same time I recognize that the understandings of Jesus found in other religions also diverge in almost countless ways from the way Christians see him. And even though some of these interpretations of who Jesus is contradict what Christians believe, they still have the capacity to inspire people to compassion and sacrifice. It is impossible to determine the extent of this ripple effect of the life of Jesus on the lives of people of other religions in the past two millenia, and even on people who do not know his story at all, but it is surely very great.

It is also true that many of the teachings of other religions and the challenges they present to Christian doctrine are quite substantial and significant. They have caused me to stop and rethink what is really essential regarding what God has revealed in Christ. I am no longer so sure about the truth and value of certain Christian teachings as I once was, for I have concluded that some of those teachings are actually secondary and non-essential to the basic story and teachings of Christ. I will not list here precisely what these teachings are, but I hope to write about them soon in a different essay.
One of the greatest changes I find in myself when compared to when I was first studying Christian theology is that I am not so quickly put on the defensive now when it comes to doctrinal disagreement. This is true both in regard to Catholic-Protestant disputes as well as to disagreements between Christianity and other religions. My desire to step into the shoes of the other as far as possible, to sympathize more and more with their views even when they contrast with those of my own tradition is, I think, a gift of God. Indeed, this seems to be a change of attitude embraced today by more and more people of different religions. There seems to be a greater readiness in interreligious encounters to acknowledge the merits of the other's argument while simultaneously recognizing the continued value but also the possible limitations of one's inherited teaching or at least the way that teaching has been articulated. We are no longer always talking past each other, as we have so often done during the past two thousand years. We sometimes recognize that we share a common pursuit of wisdom and a common spiritual journey. We often find ourselves today, representatives of different ancient faiths, grappling with the interlocking mysteries of life, death, human identity, and hope. Can we continue to learn from each other without compromising or abandoning the most precious insights of our wisdom traditions? How far can our doctrines bend and adjust themselves to the insights of the other without breaking? That is something each person must decide for herself.

Many years ago, in a remark I can no longer find, Raimon Panikkar (1918-2010), one of the great pioneers of Hindu-Christian interaction, observed that in addition to the three classical Hindu spiritual paths (margas) of inner knowledge (jnana), selfless action 
(karma), and loving devotion to God (bhakti) a new fourth path has emerged in modern times. This is the path of interreligious dialogue. Such dialogue can be spiritually transformative for each person involved in the encounter. It is more than an exchange of information about one's religion. It is ideally deeper than that. Sometimes in deep personal exchange with a person of another religion, especially when discussing the mystery of the divine, when heart speaks to heart in openness and humility, we may find ourselves suddenly enveloped by a palpable presence of God. We are reminded then of how much greater God is than any of our religions. In such encounters we sometimes find ourselves in the presence of the divine who is shining in the face of the other, an other whose doctrines are sometimes very different from our own. I believe that the God revealed in such encounters is a God of love who is at work in all the religions of the world, a God who creates community, even across religious boundaries, even when our doctrines don't agree.

And I also see more clearly now than before how love and kindness are what is most important in what we do and how they must be put into action, not just by giving alms to the poor and oppressed, but also by working for social transformation. This approach to religious interaction was stated very well in Bombay more than half a century ago by Pope Paul VI in his address to the Indian people, especially to Hindus:

You, too, are engaged in the struggle against the ills that darken the lives of

\section{Notes}

${ }^{1}$ This started to change among European Catholic theologians during the early 1980s. Hans Küng, a Swiss, having been removed from his position teaching Catholic theology at the University of Tübingen, because of accusations of innumerable people all over the world: against poverty, hunger and illness; you too are fighting the relentless battle for more food, clothing, housing, for education, for a just distribution of the wealth of this world. Are we not all one in this struggle for a better world, in this effort to make available to all people those goods which are needed to fulfil their human destiny and to live lives worthy of the children of God? Therefore we must come closer together ... with our hearts, in mutual understanding, esteem and love. We must meet not merely as tourists, but as pilgrims who set out to find God not in buildings of stone but in human hearts. Man must meet man, nation meet nation, as brothers and sisters, as children of God. In this mutual understanding and friendship, in this sacred communion, we must also begin to work together to build the common future of the human race. Such a union ... cannot be built on a universal terror or fear of mutual destruction; it must be built on the common love that embraces all and has its roots in God, who is love. ${ }^{3}$

So let us, Hindus and Christians, continue to learn from each other about the mystery of God and the divine will as it is disclosed to us in different ways in our different traditions of faith, as we journey forth to the divine, and let us put this love into action for the good of the world. And let us never forget that love, as St. Paul declared in his First Letter to the Corinthians 13:13, is the deepest of all mysteries and the greatest goal of all.

heresy, turned his scholarly attention to other religions. Walter Kasper, also from Tübingen and for many years now a Cardinal in Rome, attended with great satisfaction (I know, because I was there) a Hindu-Christian theological conference in Austria in 1983. Around that time Karl Rahner of 
Germany and Piet Schoonenberg, from the Netherlands, both discovered the Hindu teaching of non-duality (advaita) and wrote approvingly of it.

${ }^{2}$ By salvation I mean full union of the human person with God, full participation of the human person in the life of love and self-knowledge of the divine, whereby the human being is transformed into a perfect expression or likeness of the divine.

${ }^{3}$ This is from his "Address to the Members of Non-Christian Religions" from December 3, 1964. See http://www.clerus.org/bibliaclerusonline/en Lgou.htm 